\title{
WAR AND GENOCIDE IN SOUTH SUDAN
}





\section{WAR AND \\ GENOCIDE IN \\ SOUTH SUDAN}

Clémence Pinaud 
This work was partially funded by the Office of the Vice Provost of Research and the IU Libraries.

Publication of this open monograph was the result of Indiana University's participation in TOME (Toward an Open Monograph Ecosystem), a collaboration of the Association of American Universities, the Association of University Presses, and the Association of Research Libraries. TOME aims to expand the reach of long-form humanities and social science scholarship including digital scholarship. Additionally, the program looks to ensure the sustainability of university press monograph publishing by supporting the highest-quality scholarship and promoting a new ecology of scholarly publishing in which the authors' institutions bear the publication costs.

Funding from Indiana University made it possible to open this publication to the world.

\section{Copyright @ 2021 by Clémence Pinaud}

The text of this book is licensed under a Creative Commons AttributionNonCommercial 4.0 International: https://creativecommons.org/licenses/by-nc/ 4.0/legalcode. To use this book, or parts of this book, in any way not covered by the license, please contact Cornell University Press, Sage House, 512 East State Street, Ithaca, New York 14850. Visit our website at cornellpress.cornell.edu.

First published 2021 by Cornell University Press

Library of Congress Cataloging-in-Publication Data

Names: Pinaud, Clémence, 1985- author.

Title: War and genocide in South Sudan / Clémence Pinaud.

Description: Ithaca [New York] : Cornell University Press, 2021. | Includes bibliographical references and index.

Identifiers: LCCN 2020012518 (print) | LCCN 2020012519 (ebook) | ISBN 9781501753008 (paperback) | ISBN 9781501753022 (pdf) | ISBN 9781501753015 (epub)

Subjects: LCSH: Sudan People's Liberation Army. | Genocide-South SudanHistory-21st century. | Civil war-South Sudan. | Ethnic conflict-South Sudan. | Civilians-Violence against-South Sudan. | Minorities-Abuse ofSouth Sudan. | Political violence-South Sudan. | South Sudan-Politics and government-2005-2011. | South Sudan-Politics and government-2011- | Sudan-History-Civil War, 1983-2005.

Classification: LCC DT159.9295. P56 2021 (print) | LCC DT159.9295 (ebook) | DDC $962.9 / 04-\mathrm{dc} 23$

LC record available at https://lccn.loc.gov/2020012518

LC ebook record available at https://lccn.loc.gov/2020012519

Cover illustration: SPLA car, Unity state, 2016. Art courtesy of the author. 